\title{
Experiencia histórica sublime, presencia real y fotografía
}

\section{Sublime Historical}

\section{Experience,}

Real Presence and

Photography

\author{
Martin Jay \\ University of California, Berkeley \\ martjay@berkeley.edu
}

\author{
Traducción de Gibrán Larrauri Olguín \\ Universidad Iberoamericana, Ciudad de México, México \\ gibran.larrauri@gmail.com
}

* Este artículo fue originalmente publicado como: "Sublime Historical Experience, Real Presence and Photography" en Journal of the Philosophy of History 12 (2018): 431-448. DOI: $10.1163 / 18722636-12341406$ 


\section{Resumen}

Además del testimonio de la propia "experiencia histórica sublime" del autor durante una visita al campo de concentración de Theresienstadt, este ensayo se basa en el análisis de Georges Didi-Huberman de cuatro fotografías del Holocausto en su Images in Spite of All, para demostrar el poder del argumento de Ankersmit. Especula sobre la relación entre esas experiencias y las nociones teológicas de la "presencia real", la cual, además, busca colapsar la distancia entre el pasado y el presente, y confundir las nociones historicistas convencionales de continuidad temporal y determinación contextual. Contra la declaración de Ankersmit, que sostiene que las experiencias históricas sublimes ocurren sólo cuando una transformación civilizatoria provoca nostalgia por un pasado perdido, este artículo argumenta que, tal vez, también se puedan sentir cuando acontecimientos traumáticos, cuyo retorno nadie anhela, interrumpen la inteligibilidad de las narrativas históricas y la representación significativa.

Palabras clave: Presencia real, Didi-Huberman, Holocausto, Theresienstadt, punctum fotográfico, trauma, acontecimiento 

Siempre he considerado una gran suerte haber sido uno de los primeros en responder a la audaz y original defensa de Frank Ankersmit de lo que él llamó "experiencia histórica sublime”. Por casualidad, ambos estábamos lidiando con el concepto de experiencia y sus vicisitudes al mismo tiempo, durante los primeros años de este siglo, así pudimos iniciar un fructífero diálogo, cuyos benéficos resultados encontraron sus caminos en libros que ambos publicamos en 2005. ${ }^{1}$ Intercambiamos capítulos y serví como lector de su manuscrito para la Stanford University Press, en el cual me basé ampliamente — citando el título que luego él abandonó: Historical Experience: The Embrace of Romeo and Juliet - para mi capítulo sobre conceptos de experiencia histórica, cuyos otros grandes protagonistas fueron Wilhelm Dilthey, R. G. Collingwood y Joan Scott. Hice mi mejor esfuerzo para resumir la esencia de su argumento, que, por un lado, buscaba ambiciosamente ir más allá de la teoría de correspondencia de Dilthey y Collingwood, con sus nociones de reexperimentar el presente o recrear las experiencias de actores pasados; $y$, por el otro, superar el desdén posestructuralista de Scott por la experiencia tout court. Aunque me preocupaba la desafiante evasión de Ankersmit de las preguntas epistemológicas sobre el valor verdadero de los relatos de experiencias históricas sublimes, en favor de su justificación estética, ${ }^{2}$ y sin tener claro

Frank Ankersmit, Sublime Historical Experience (Stanford: Stanford University Press, 2005); Martin Jay, Songs of Experience: Modern and American and European Variations on a Universal Theme (Berkeley: University of California Press, 2005). Un tercer compañero en nuestra conversación fue un académico más joven, Craig Ireland, cuyo libro The Subaltern Appeal to Experience: Self Identity, Late Modernity, and the Politics of Immediacy (Montreal: McGill-Queen's University Press, 2004) apareció un año antes. Este último libro ha generado una atención considerable, con algunos devotos de su enfoque narrativista anterior; por ejemplo, Peter Icke y Keith Jenkins, quienes han expresado consternación por lo que vieron como la traición de su mejor yo; y otros, por ejemplo, Ewa Domanska, aplaudieron su nueva perspectiva.

2 Ankersmit, que califica su enfoque como francamente "romántico", afirma con audacia que "la afirmación de que existe una variante de la experiencia que precede y trasciende las cuestiones de verdad y falsedad es precisamente la tesis principal de este libro". Sublime Historical Experience, 9. 
cómo se podría transformar la experiencia de un historiador individual - lo que él reconoció como un evento raro e inefable — en garantía para una nueva narrativa o representación del pasado que podría ser juzgada por la comunidad de historiadores, encontré el concepto en sí intrigante.

Buena parte de esta razón se debió a su resonancia con un encuentro extraordinario que yo mismo tuve una vez con el pasado, que ahora era iluminado por el análisis de Ankersmit de las sublimes experiencias históricas. Yo lo había descrito con cierto detalle en un ensayo publicado en 1995 titulado "The Manacles of Gavrilo Princip". ${ }^{3}$ Durante una visita al campo de concentración nazi en Theresienstadt el año anterior, había llegado inesperadamente a la celda donde el asesino adolescente del archiduque Franz Ferdinand se pudrió hasta su muerte en 1918, unos meses antes del final de la horrible guerra precipitada por su acto violento. Mientras sostenía las cadenas oxidadas que habían atado al miserable muchacho al suelo de su jaula, me salí de la melancólica narrativa del Holocausto que había seguido mientras atravesaba el campo. Fue, recordé más tarde, "como si de repente en las páginas de Middlemarch alguien hubiera introducido subrepticiamente un capítulo, digamos, de $L a$ cartuja de Parma". ${ }^{4}$ Incluida en mi narración del Holocausto había una triste rumia sobre la vida truncada del poeta, dramaturgo y fabricante de títeres Petr Kein, un joven con quien me identifiqué y uno de cuyos títeres estaba a la vista en el museo del campo. “¿Cómo — me preguntépodría conciliar mi admiración reverencial por las manos talentosas de

Aunque el argumento de que existe una experiencia primordial anterior al juicio lingüístico de verdad o falsedad es plausible, como los fenomenólogos han sostenido durante mucho tiempo, estoy menos persuadido de que se pueda decir que "trascienda" tales juicios, al menos para la comunidad de historiadores. Para una discusión más profunda de este tema, ver David Carr, Experience and History: Phenomenological Perspectives on the Historical World (Oxford: Oxford University Press, 2014), y mi reseña en Journal of the Philosophy of History, 10 (2016): 325-331.

Martin Jay, "The Manacles of Gavrilo Princip”, Salmagundi 106/107 (1995): 14-21, reimpreso en Martin Jay, Cultural Semantics: Keywords of Our Time (Amherst: University of Massachusetts Press, 1998). Jay, Cultural Semantics, 202. 
un joven titiritero inocente con la conmoción que sentí en la 'presencia' de las manos esposadas de un asesino infame?".

Mi respuesta fue reflexionar sobre el entrelazamiento del Holocausto con la violencia desatada por la Primera Guerra Mundial y la catástrofe que aún se desarrollaba en los Balcanes tras la desintegración de Yugoslavia, la cual implicó nuevas variantes de la limpieza étnica que había alcanzado su apogeo en el exterminio nazi de los judíos. Por lo tanto, me vi llevado a reflexionar sobre la cualidad inextricable del Holocausto, por mucho que uno quisiera protestar de su inefable singularidad, dentro de la red de horrores desencadenados por la bala de un asesino que aún sigue hilándose ochenta años después. Pese los peligros de la "relativización" o la "normalización", concluí que estaba mal transfigurar el Holocausto en una erupción cuasi-metafísica de lo demoníaco en el turbulento flujo de sucesos históricos. Incluso el imperativo "nunca más" tenía sentido sólo si uno reconocía implícitamente que eso, o algo muy parecido, podría suceder más de una vez.

Tales fueron mis intentos de dar sentido al recuerdo material inesperado de la Primera Guerra Mundial en uno de los lugares más inquietantes de la Segunda. De lo que no pude darme cuenta en ese momento, fue que en muchos sentidos mi encuentro con las esposas de Gavrilo Princip podía entenderse provechosamente en los términos que Ankersmit desarrollaría en Sublime Historical Experience. Quizá su movimiento más atrevido en esa obra fue defender un encuentro intenso con un pasado que se negaba no sólo a ser explicado en términos causales, sino también a ser interpretado como significativo. Ciertas experiencias poderosas en el presente de realidades pasadas, argumentó, desafían los intentos de narrarlas o representarlas en términos inteligibles. No pueden ser domesticadas, dice Hayden White, al ubicarlas en historias guiadas por tropos prefigurados de trama. Frustran todos los esfuerzos, dice 
Quentin Skinner, de reducirlas a intervenciones en un contexto histórico particular disponible para la reconstrucción actual. Su sublimidad radica precisamente, como han sostenido célebres estudiosos de lo sublime como Burke y Kant, en su resistencia a la representación o explicación, al estar más allá de la capacidad del mero lenguaje para redescribirlos en términos comunicables. Oportunamente, mi ensayo sobre la visita a Theresienstadt terminó con una recolección de mi reacción inarticulada ante la experiencia de sujetar las esposas de Princip: "el impulso que me abrumaba era el de sacudirlas tan furiosamente como pudiera, mientras gritaba impotentemente al fantasma del chico que una vez las llenó del epíteto terrenal que los habitantes de Theresienstadt habrían entendido demasiado bien: iiildiota!!!””. ${ }^{6}$

Mi furia visceral y farfullante contra el fantasma de Princip encajó con la afirmación de Ankersmit de que algunas experiencias del pasado tienen un efecto emocional no mediado por historiografía previa, tal vez filtradas a través de categorías tradicionales de comprensión. Más que basarse en la imparcialidad desinteresada, instigada por la distancia visual, las experiencias participan de la inmediatez de la interacción háptica, en la cual tomamos con nuestras propias manos un residuo material — digamos, las cadenas oxidadas en una celda de prisión- que ha sobrevivido al pasado. Vienen a nosotros, además, espontáneamente y sin provocación por las preguntas planteadas al pasado o por las hipótesis sobre él que ponemos a prueba, sopesando cuidadosamente las evidencias. Similar a la "memoria involuntaria" de Bergson, la cual Walter Benjamin relacionó con los residuos no asimilados del trauma, Ankersmit escribió: "de repente se presenta a sí misma como una invasión meteórica del pasado al presente. Todo lo que nos rodea en el presente se hace a un lado y el mundo entero se reduce a nosotros mismos en esta memoria específica, donde la memoria nos ve, por así decirlo, y nosotros sólo vemos eso". ${ }^{7} \mathrm{Si}$

Jay, Cultural Semantics, 204.

Ankersmit, Sublime Historical Experience, 187. 
tal experiencia tiene algún valor de verdad, es el de una verdad reveladora similar a la aletheia de Heidegger, basada en la receptividad pasiva más que en el interrogatorio activo. Es lo que Huizinga parece haber buscado: "una verdad que surge de una unión cuasi mística con el mundo que ya no se deja encantar por las abstracciones que todos usamos sin problemas. Es un misticismo que no nos aleja de la realidad, sino que nos lleva a su corazón". ${ }^{8}$ Más que un encuentro subjetivo con un objeto externo, en esta experiencia el sujeto pierde cualquier poder constituyente, tal vez, incluso, su sentido de autonomía individual, se ve abrumado por el poder de la emoción. La distinción entre sujeto y objeto flaquea, y lo que queda es experiencia sin una noción fuerte del sujeto que la tiene. Aunque se apartó de aceptar el irracionalismo místico, Ankersmit argumentó que "la experiencia histórica une los rostros del pasado y el presente en un beso corto pero extático". 9

No hubo nada muy romántico en mi visita a Theresienstadt, mucho menos una pizca de unión mística con el mundo, a pesar de ello, experimenté el poder emocional de lo que en mi ensayo había llamado "la 'presencia' de las manos esposadas de un infame asesino". Al hacerlo, anticipé, sin darme cuenta, un término clave del discurso de la experiencia histórica sublime, aunque quizá se encuentra explícito en primer plano en el trabajo de los dos aliados más importantes de Ankersmit: Hans Ulrich Gumbrecht y Eelco Runia. ${ }^{10}$ Todos destacan la importancia de la

$8 \quad$ Ankersmit, Sublime Historical Experience, 137.

9 Ankersmit, Sublime Historical Experience, 121. De ahí su evocación de Romeo y Julieta, quienes escapan de los contextos restrictivos de sus familias. Contrariamente a su rechazo del misticismo irracionalista, un crítico del libro, Michael Roth, comenta con escepticismo que "a este lector le parece que éste es precisamente el dominio en el que Ankersmit se ha visto obligado a entrar, porque ésta es la única alternativa que le queda después de rechazar el pragmatismo, la hermenéutica y la problemática de la representación”. Michael Roth, "Ebb Tide”, History and Theory 46 (2007): 69.

10 Hans Ulrich Gumbrecht, Production of Presence: What Meaning Cannot Convey (Stanford: Stanford University Press, 2004) y Eelco Runia, Moved by the Past: Discontinuity and Historical Mutation (Nueva York: Columbia University Press, 2014), capítulo 3. Sus posiciones no son, sin duda, 
poderosa presencia de aquello que Runio llamó un "polizón” del pasado. Para Ankersmit una combinación de ausencia y presencia define la experiencia histórica sublime: la ausencia del marco narrativo representativo mediador, explicativo y contextual, y la presencia de una "sensación" directa - término tomado de Huizinga- de un pasado que se inmiscuye en nuestra conciencia.

Un posible precedente de esta versión elevada de un pasado manifiesto ontológicamente en el aquí y el ahora es la doctrina cristiana de la "presencia real", la transubstanciación del cuerpo y la sangre de Jesús crucificado en la Eucaristía. Como los historiadores han entendido desde hace mucho tiempo, puede ocurrir un cierto deslizamiento de una presencia explícitamente divina a una más secular, en la cual la creencia en la identidad literal de la Sagrada Eucaristía ${ }^{11}$ y Cristo podría, de alguna manera, ser transferida, al menos en parte, a otras figuras semisagradas. Un ejemplo sobresaliente fue la doctrina medieval de los dos cuerpos del rey: uno comparable al eterno corpus mysticum de Cristo, el otro a su contraparte mortal y su carácter de criatura. ${ }^{12}$ Una manifestación posterior de esta transformación milagrosa apareció, según sostuvo el

perfectamente equivalentes. Para un análisis de las diferencias de Ankersmit con Runia, ver: Anton Froeyman, "Frank Ankersmit y Eelco Runia: The Presence and Otherness of the Past", Rethinking History 16 (2012): 393-415. En una entrevista con Marcin Moskalewicz, Ankersmit dijo: "Acabo de leer el libro de Gumbrecht sobre la presencia; y ahí se ven casi las mismas cosas, aunque Gumbrecht, creo, no es suficientemente consciente de todas las complicaciones filosóficas involucradas en todo esto". Marcin Moskalewicz, "Sublime Experience and Politics: Interview with Professor Frank Ankersmit", Rethinking History 11 (2007): 255.

11 Para una descripción de su continua importancia en términos estéticos, ver George Steiner, Real Presences (Chicago: University of Chicago Press, 1991). Para una discusión de la importante distinción entre la identidad ontológica subyacente a la doctrina de la Sagrada Eucaristía y la representación icónica o imaginaria, ver Catherine Gallagher y Stephen Greenblatt, Practicing New Historicism (Chicago: University of Chicago Press, 2000), capítulo 3.

12 Ernst H. Kantorowicz, The King's Two Bodies: A Study in Medieval Theology (Princeton: Princeton University Press, 1957). 
historiador Louis Marin, en el retrato de Luis XIV en monedas y medallas durante el periodo moderno temprano. "El rey sólo es verdaderamente rey, es decir, monarca — escribe-, en imágenes. Son su presencia real. Es obligatorio creer en la efectividad y operatividad de sus signos icónicos, o de lo contrario, el monarca se vaciará de toda su sustancia por falta de transubstanciación y sólo quedaría el simulacro". ${ }^{13}$ El cuerpo del rey es a la vez sacramental, simbólico e histórico, en tanto su presencia física se transfigura en la presencia real de una imagen que es más que una mera semblanza o semejanza. Aunque los teólogos a menudo tuvieron cuidado de diferenciar la identidad ontológica en la Eucaristía, tanto del aura sagrada de los íconos como de la imitación representativa de meras imágenes, parte de la magia asociada con la primera puede viajar hacia la segunda.

La ulterior transformación de tales imágenes devocionales, religiosas o políticas, con potencia sacramental en objetos de arte con valor estético únicamente, trazada por Hans Belting en su Likeness and Presence, es un elemento fundamental en la famosa narrativa de la modernización como secularización. ${ }^{14}$ Cualquier aura de santidad que pudiera adherirse a residuos tan controvertidos de una era anterior como el Sudario de Turín, el mundo moderno en general perdió la fe en la magia de un ícono como una huella directa de divinidad, un archeiropoietos no hecho por las manos de hombres, presente en la imagen del pañuelo de santa Verónica que enjugaba el rostro de Jesús camino hacia la cruz.

O mejor dicho, la sanción religiosa para tales creencias ha disminuido, pero tal vez algo de su poder perdura, incluso en pensadores declaradamente seculares como Ankersmit. En lo que sigue, quiero considerar las

13 Louis Marin, Portrait of the King, Martha M. Houle, trad. (Minneapolis: University of Minnesota Press, 1988), 8.

14 Hans Belting, Likeness and Presence: History of the Image before the Era of Art, Edmund Jephcott, trad. (Chicago: University of Chicago Press, 1994). 
maneras en que la sublime experiencia histórica, como la ha descrito Ankersmit, puede extender su poder para considerar el papel de la fotografía en la producción de tales experiencias. De hecho, ese papel ha sido reconocido tanto por Runia como por Ankersmit. En el Moved by the Past del primero, se afirma que las fotografías introducidas por W. G. Sebald en su novela Austerlitz "funcionan como fístulas o agujeros en los que el pasado descarga el presente... Las ilustraciones de Sebald son una especie de 'filtración' en el tiempo, a través de la cual la 'presencia' brota del pasado al presente". ${ }^{15}$ En Sublime Historical Experience, Ankersmit cita con aprobación la apreciación de Walter Benjamin sobre las fotografías de Eugène Atget del París de finales del siglo xIx: "El argumento de Benjamin es que la apertura o indeterminación que es el corazón y la esencia del presente es, de alguna manera, conservado en la fotografía, de modo que ésta produce en nosotros una convicción de ser momentáneamente contemporáneos con la escena representada por la fotografía. ${ }^{16}$ Agrega que Benjamin elogió a Atget por preservar la realidad del pasado, que era casi como un fósil, "por la ausencia de cualquier rastro de actividad humana... como si tuviéramos éxito en llegar al pasado a través de una capa indiferente al tiempo de la cual, por lo general, están desprovistos todos los proyectos y planificaciones humanos sometidos al tiempo" ${ }^{17}$ Tales imágenes, vacías de calor humano, también están vacías de significados profundos, todo es superficial y sin profundidad, proporciona la experiencia de lo que Benjamin llamó memorablemente "la escena del crimen”. Pasando a una discusión del análisis de Benjamin sobre la mirada desinteresada del flâneur, Ankersmit suma "el ojo opera aquí como el sentido del tacto; el ojo entonces resiste firmemente la ten-

Runia, Moved by the Past, 67.

Ankersmit, Sublime Historical Experience, 182.

Ankersmit, Sublime Historical Experience, 184. 
dencia tan natural para él de buscar verdades detrás de cómo el mundo aparece ante nosotros". ${ }^{18}$

Tal análisis del poder de la fotografía, señala Ankersmit en una nota a pie de página, recuerda la famosa distinción de Roland Barthes entre el studium de una imagen fotográfica y su punctum, en la cual también se basa Runia. ${ }^{19}$ El primero depende de un contexto inteligible de significado en donde la fotografía pueda insertarse cómodamente, por ejemplo, una narración en la que funciona como un episodio de una historia trazada, de hecho, como lo que Henri Cartier-Bresson llamó una vez el "momento decisivo" de esa historia. ${ }^{20}$ El studium depende de un código cultural compartido, permite al espectador interpretar su significado. Las emociones que despierta son moderadas, comedidas, dóciles, más del orden del mero "me agrada", que de la apasionada intensidad del "lo amo". Está del lado de la convención y el "buen gusto" artístico. En contraste, el punctum fotográfico de Barthes excede la codificación convencional, produciendo una poderosa carga emocional única para el espectador individual. Acentúa de forma brusca e inesperada el flujo de coherencia narrativa, se siente más como una herida física punzante que como una mirada serena a la distancia. Como una experiencia traumática, resiste el cierre fácil en un mundo tranquilizador de significado coherente que promete el studium. Como argumentó Ulrich Baer en Spectral Evidence, penetrante análisis barthesiano de la fotografía del trauma: "las fotografías son inquietantes. Algunas imágenes pasan por alto los meticulosos intentos de contextualización y entregan, directamente y aparentemente a través del abismo de tiempo entre el espectador y el pasado fotografiado momificado, una poderosa ilusión de lo real”. ${ }^{21}$

18 Ankersmit, Sublime Historical Experience, 185.

19 Ankersmit, Sublime Historical Experience, 424. Ver Roland Barthes, Camera Lucida: Reflections on Photography, Richard Howard, trad. (Nueva York: Hill and Wang, 1981). Runia lo invoca en Moved by the Past, 100-103.

20 Henri Cartier-Bresson, The Decisive Moment (Nueva York: Simon and Schuster, 1952).

21 Ulrich Baer, Spectral Evidence: The Photography of Trauma (Cambridge: MIT Press, 2005), 2. 
Se puede decir mucho más sobre las implicaciones de la distinción de Barthes, pero está claro que nos ayuda a comprender a qué se refiere Ankersmit en su defensa de las experiencias históricas sublimes, esos encuentros inusualmente intensos y cargados de emociones con el pasado, los cuales se niegan, como los punctums de las fotografías, a estar contenidos en marcos convencionalmente explicativos o hermenéuticos. La relevancia potencial de la fotografía va más allá de los argumentos generales de Barthes; esto se puede mostrar si nos dirigimos ahora a un debate particularmente controvertido suscitado en 2001 por la publicación del catálogo de una exposición en París llamada Mémoire de camps: Photographies des camps de concentration et d'extermination nazis, el cual incluía cuatro notables fotografías del exterminio real tomadas en Auschwitz. El ensayo que acompańa al catálogo fue escrito por el distinguido teórico e historiador de la fotografía Georges Didi-Huberman. Casi de inmediato fue recibido con indignación en las páginas de Les temps modernes en dos artículos de Gérard Wajcman y Elisabeth Pagnoux, quienes se aliaron con las apasionadas denuncias de la representación visual del Holocausto hechas por Claude Lanzmann, director del aclamado documental Shoah y editor en jefe de Les temps modernes. ${ }^{22}$ Didi-Huberman publicó su larga refutación dos años después en un libro traducido en 2008 al inglés como Images in Spite of All: Four Photographs from Auschwitz. ${ }^{23}$

22 Gérard Wajcman, "De la croyance photographique” y Elisabeth Pagnoux, "Reporter photographique à Auschwitz", Les temps modernes, núm. 613, 56 (2001): 47-83 y 84-108.

23 Georges Didi-Huberman, Images in Spite of All: Four Photographs from Auschwitz, Shane B. Lillis, trad. (Chicago: University of Chicago Press, 2008). Para una discusión sobre la controversia de las imágenes del Holocausto, ver: Janina Struk, Photographing the Holocaust: Interpretations of the Evidence (Londres: I.B. Tauris, 2004). Las cuatro imágenes de Auschwitz continúan perturbando la representación visual normal. En 2014, el pintor Gerhard Richter intentó reproducirlas a lápiz y luego recrearlas en su característico estilo borroso. Finalmente, "pintó de más” los lienzos, titulados Birkenau, y escurrió la superficie, destruyendo cualquier vestigio de forma y dejando una mancha de negros, grises y blanco ceniza con manchas de verde y rojo sangre. 
Las imágenes en cuestión son únicas en varios aspectos, esto las convierte en más que ejemplos típicos de fotografías que sirven como evidencia documental del pasado. En cambio, muestran el poder que algunas tienen para servir como manifestaciones secularizadas de la "presencia real", que produce experiencias sublimes del pasado. A diferencia de las 40000 imágenes de Auschwitz fabricadas por los nazis, perversamente determinados a dejar constancia de sus hechos para la posteridad, éstas fueron tomadas subrepticiamente por Sonderkommandos, prisioneros judíos seleccionados por sus captores para ayudar en el asesinato de sus compañeros de prisión. ${ }^{24}$ En 1944, la Resistencia polaca, con la esperanza de adquirir un registro de los asesinatos, introdujo de contrabando una cámara en el fondo falso de un balde. Dos imágenes fueron tomadas por un judío griego llamado Alex — no tenemos su apellido- desde dentro de una cámara de gas dañada que no funcionaba en el crematorio v; otras dos fueron instantáneas borrosas tomadas fuera del crematorio, posiblemente mientras el fotógrafo se alejaba en silencio. Luego se volvió a colocar la cámara en el balde y la película se dispuso en un tubo de pasta de dientes que encontró su camino con una nota de acompañamiento, la cual explicaba su origen y contenido a la Resistencia. En las cuatro imágenes, vislumbramos lo que parece ser la cremación de cuerpos gaseados y mujeres conducidas a las cámaras de gas.

Recortadas y formateadas, estas imágenes se habían hecho públicas antes y habían servido como ilustraciones documentales icónicas del Holocausto. Pero Didi-Huberman insistió en su introducción a la exposición, con base en que eran más valiosas en su estado crudo y sin retoques, con grandes franjas de negro, borrosas y descentradas. "Sin

24 Ulrich Baer, que examina el uso que se hace de las fotografías en color del gueto de Łódź en la película Fotoamator de Dariusz Jablonski, considera sugestivamente la posibilidad de convertir las imágenes producidas por "la mirada nazi" en contra de las intenciones de sus fotógrafos. Baer, Spectral Evidence, capítulo 4. 
duda se creía que el recorte de estas imágenes preservaba el documento (el resultado visible, la información distinguible) —escribió-. Pero en cambio, se eliminó su fenomenología, todo lo que las convertía en un acontecimiento (un proceso, un trabajo, un contacto físico)" ${ }^{25}$ Aunque su poder se magnificó por su yuxtaposición en un montaje modesto, su integridad física era vital para su valor duradero. Porque lo que no se veía en las imágenes no era menos revelador que lo que sí. Como gesto de desafío, eran más que simples registros de lo que se conservaba en la propia película, meros fragmentos de una máquina aniquiladora mucho más grande y compleja. También fueron los restos sobrevivientes de los valientes actos de los Sonderkommandos cuyas vidas estaban al borde de la extinción, produciendo imágenes "a pesar de todo".

El desprecio acumulado hacia Didi-Huberman en Les temps modernes fue alimentado por el discurso antiocularcéntrico tan influyente en el pensamiento francés moderno, el cual traté de rastrear en Downcast Eyes. ${ }^{26} \mathrm{La}$ desconfianza de las imágenes como inferiores al testimonio verbal es palpable en la práctica cinematográfica de Lanzmann, la cual también aporta a las críticas hacia Didi-Huberman. Pero sus autores hicieron tres objeciones más específicas. Primero, acusaron a Didi-Huberman de haber sucumbido a una fetichización religiosa de la imagen como una especie de reliquia sagrada, lo cual era de origen inherentemente cristiano. En segundo lugar, afirmaron que había alimentado los impulsos

25 Didi-Huberman, Images in Spite of All, 36.

26 Martin Jay, Downcast Eyes: The Denigration of Vision in Twentieth-Century French Thought (Berkeley: University of California Press, 1993). Didi-Huberman señala que "un rasgo característico de esta 'resistencia a la imagen' es la adopción espontánea de formas tradicionales de iconoclastia política: el rechazo absoluto, la retórica de la censura moral, el deseo de destruir los 'ídolos". Images in Spite of All, 64. También se podría señalar que la desconfianza hacia las fotografías por su incapacidad para capturar la duración, una crítica que se remonta al menos a Bergson, a menudo ha informado las respuestas de los historiadores sobre ellas. Ver Michael S. Roth, "Photographic Ambivalence and Historical Consciousness", History and Theory, número temático 48 (2009): 83-86. 
voyeristas perversos de la cultura contemporánea, contribuyendo así a una pornografía de violencia no ética o "goce en el horror" ${ }^{27}$ En tercer término, lo acusaron de una violación más generalizada del saludable tabú en contra de intentar imaginar lo inimaginable, hacer visible lo que estaba fuera de cualquier ilustración o representación. Todas esas imágenes, criticaron sus acusadores, son mentiras porque sólo pueden capturar una parte minúscula del todo, el cual nunca podrá mostrarse en su totalidad. En cambio, como Lanzmann había demostrado en Shoah, el alegato de los testigos es mucho más potente para preservar la memoria del Holocausto. "Siempre he dicho — argumentó Lanzmann- que las imágenes de archivo son imágenes sin imaginación. Petrifican el pensamiento y matan cualquier poder de evocación. Vale mucho más hacer lo que yo hice, un inmenso trabajo de desarrollo de creación de la memoria de un acontecimiento". ${ }^{28}$

La larga y enérgica respuesta de Didi-Huberman reunió muchos argumentos diferentes, basándose en todo: desde el estado del archivo histórico hasta el uso del montaje en el cine, invocando una variedad de teóricos desde Lacan y Bataille hasta Benjamin y Kracauer. Las respuestas que produjo, relevantes para la pregunta más amplia que estamos planteando sobre el valor de la experiencia histórica sublime, son las siguientes. Contra la acusación de fetichismo, tomando la parte por el todo, Didi-Huberman desafió la suposición de que cualquier relato, ya sea basado en fuentes escritas, testimonios o imágenes, puede reclamar un recuerdo total. Por tanto, es erróneo concluir que, dado que la fotografía es un mero fragmento incapaz de mostrar el todo, no muestra nada en absoluto. Las palabras también sufren de la misma insuficiencia a la hora de describir e interpretar hechos históricos, a fortiori uno tan inmenso e

\footnotetext{
27 La frase de Pagnoux es citada en Didi-Huberman, Images in Spite of All, 55.

28 Citado en Didi-Huberman, Images in Spite of All, 93.
} 
inefable como el Holocausto. Los archivos nunca reflejan perfectamente los acontecimientos cuyas huellas conservan, pero ellos mismos tienen sesgos ideológicos y lagunas inevitables que requieren técnicas de montaje y verificación, las cuales permitan al historiador reconstruir el pasado. Los testimonios no son menos parciales, distan mucho del absolutismo asumido por Lanzmann y sus discípulos.

Tampoco es correcto, continuó Didi-Huberman, asumir que todas las imágenes son iguales, asimilando así a víctimas y victimarios en un espectáculo sin fisuras para que un voyeur distante lo contemple estéticamente. Las cuatro imágenes en cuestión, en efecto, contrastan con las miles de otras tomadas por los perpetradores: "son un sintoma histórico capaz de romper, y reconfigurar, la relación que habitualmente mantiene el historiador de imágenes con sus propios objetos de estudio. En este caso extremo, por lo tanto, hay algo que cuestiona nuestro propio ver y nuestro propio saber" ${ }^{29}$ Contra los intentos de narrar o representar el Holocausto como una historia completamente inteligible, brindan una experiencia muy diferente, una que funciona para cuestionar la sabiduría recibida. Nos obligan, escribe Didi-Huberman, "a distinguir, en el inmenso corpus de imágenes de los campos de exterminio, entre lo que vela y lo que desgarra. Lo que sostiene la imagen en su regla consensuada (donde nadie mira realmente) y lo que hincha la imagen hacia su excepción desgarradora (donde de repente todos se sienten mirados)" ${ }^{30}$ Tales "desagarra-imágenes" producen una sensación de vértigo en el observador actual, que no se reconforta al ver lo que espera: "estas imágenes nunca serán imágenes tranquilizadoras de uno mismo; siempre serán imágenes del Otro, horrorosas, desgarradoras imágenes como tales, pero su propia otredad exige que nos acerquemos a ellas... la identidad se altera: por un instante, el sujeto que mira, por firme que sea en el ejercicio de la

\footnotetext{
29 Didi-Huberman, Images in Spite of All, 57.

30 Didi-Huberman, Images in Spite of All, 81.
} 
observación, pierde toda certeza espacial y temporal" ${ }^{31}$ Las imágenes-velo, por el contrario, son los verdaderos fetiches, en la medida en que, según Lacan, producen imágenes pantalla o "imágenes de escudo", que pueden anestesiar al espectador y oscurecer en lugar de revelar la verdad.

Las cuatro imágenes tomadas clandestinamente por los Sonderkommandos se entienden mejor, en términos desarrollados por Sartre, no como objetos o representaciones, sino como acciones pasadas que están ahí para nuestra cuasi-observación actual. ${ }^{32}$ Es decir, nos permiten observar ahora las acciones previas de los fotógrafos, cuyo valor desafiante desestabiliza la sabiduría recibida sobre la pasividad de las víctimas del Holocausto. A la usanza de los críticos postestructuralistas de la indexicalidad de la imagen fotográfica - el rastro físico perdurable de un evento pasado, célebremente contrastado por C. S. Peirce con los significados icónicos y simbólicos de una fotografía-, las fotografías brindan acceso en el presente a las acciones que las crearon. "Las cuatro imágenes de Birkenau —escribe Didi-Huberman — son preciosas para nosotros sólo porque ofrecen la imagen de lo humano a pesar de todo, la resistencia, por medio de la imagen — un trozo de película—, a la destrucción del humano, que no obstante está documentado". ${ }^{33}$ Como tales, pueden compararse con la supervivencia de textos cuyo poder performativo excede su mera función descriptiva, textos que hicieron que algo sucediera en el mundo. $\mathrm{O}$ mejor dicho, textos que todavía tienen el potencial de hacerlo, incluso después del paso del tiempo.

Es justo esta ambigüedad - la presencia del acto de resistencia y la ausencia de quienes perecieron después de hacerlo— lo que distingue las imágenes que Didi-Huberman defiende contra la afirmación de que las imágenes son todo o nada. Las llama "imágenes-laguna”, las define como

31 Didi-Huberman, Images in Spite of All, 88.

32 Jean-Paul Sartre, L'imaginaire (París: Gallimard, 1940), 20-28.

33 Didi-Huberman, Images in Spite of All, 161. 
una "imagen de rastro y una imagen de desaparición al mismo tiempo. Permanece algo que no es la cosa, sino una pizca de su parecido. Algo muy pequeño, una película — queda de un proceso de aniquilación: ese algo, por lo tanto, da testimonio de una desaparición y al mismo tiempo la resiste, ya que se convierte en la oportunidad de su posible recuerdo. No es presencia plena ni ausencia absoluta". ${ }^{34}$

¿Cómo se corresponde este análisis, debemos preguntarnos ahora, con la descripción de Ankersmit de la sublime experiencia histórica? Claramente, comparte con él un sentido de las formas en que los rastros del pasado, tanto los objetos visuales como los textos, pueden cobrar vida poderosamente en el presente, rastros que, de alguna manera, eluden los filtros del lenguaje y la representación para realizar algo en posteriores espectadores. También es sensible a la capacidad de estos rastros subvertir las cuadrículas explicativas y hermenéuticas recibidas, puntuando — pinchando- narrativas que imbuyen al pasado de una coherencia reconfortante, pero ilusoria. Y comparte con la sublime experiencia histórica la fe de que nos "pongan en contacto", al seguir la lógica háptica de la indexicalidad, con un pasado que tiene una presencia palpable en el aquí y ahora, incluso cuando registran lo irreparablemente diferente del pasado. Son supervivientes, como los polizones ensalzados por Runia, que ofrecen una pizca de esperanza para el futuro.

Pero, ¿qué hay de la apasionada resistencia de Didi-Huberman a la acusación de que está traficando reliquias, las cuales dependen de una noción cristiana fetichista de la redención?, ¡cómo encaja esto con la sospecha de que hay un residuo de la noción teológica de "presencia real" en la idea de Ankersmit de la experiencia histórica sublime? Didi-Huberman se esforzó en su refutación para enfatizar los orígenes judíos más que cristianos de su defensa de las cuatro imágenes de Auschwitz. 
Citando Star of Redemption de Franz Rosenzweig, los estudios de Gershom Scholem sobre el mesianismo judío, las tesis de Walter Benjamin sobre la historia y la estética cinematográfica realista y crítica de Siegfried Kracauer, argumentó que "la noción judía de redención (gẻulah) contrasta fuertemente con la noción — una noción primero cristiana, luego hegeliana, incluso marxista - de salvación histórica. Es una respuesta a la condición de exilio, pero una respuesta guiada por un 'pesimismo absoluto' sobre la historia y su progreso". ${ }^{35}$ Sin despertar a los muertos ni consolarnos por su pérdida, la imagen, en esta lectura, es redentora "sólo en escasos momentos de su desaparición; expresa el desgarro del velo a pesar de todo, a pesar de la inmediata re-velación de todo aquello que Benjamin llamaría la 'desolación del pasado'”. ${ }^{36}$

¿Implica este argumento una distinción importante entre la experiencia histórica sublime de Ankersmit y la defensa de las "imágenes a pesar de todo" de Didi-Huberman? Los dos pensadores, hay que admitirlo, difieren en sus reacciones al significado del Holocausto. Sin minimizar en modo alguno su horror, Ankersmit niega explícitamente su condición ejemplar como el tipo de herida traumática que la sublime experiencia histórica busca superar. Contra el argumento de Dominick LaCapra de que el dolor colectivo insoportable que causó el Holocausto produjo tal ruptura, sostiene que "lo que es típico del trauma es precisamente la incapacidad de sufrir o asimilar la experiencia traumática en la historia de la vida de una persona. Lo que surge con el trauma no es tanto una apertura al sufrimiento, sino un cierto entumecimiento". ${ }^{37}$ Una forma de interpretar esta distinción es asegurar que, debido a que el dolor y el sufrimiento del Holocausto siguen siendo palpables y la herida aún no cicatriza, realmente no ha proliferado la disociación radical del pasado

35 Didi-Huberman, Images in Spite of All, 169.

36 Didi-Huberman, Images in Spite of All, 170.

37 Ankersmit, Sublime Historical Experience, 353. 
perdido que genera el anhelo por su recuperación. Sus efectos son todavía demasiado perturbadores para que haya cambiado al tipo de amnesia colectiva que inconscientemente quiere ser superada. De hecho, argumenta Ankersmit, "lo que Hitler y sus secuaces dejaron a la posteridad es algo que debería evitarse para siempre y que bajo ninguna circunstancia podría ser una parte legítima de nuestro presente y nuestro futuro". ${ }^{38} \mathrm{~A}$ diferencia de la perdida sociedad agraria feudal, suplantada por el mundo industrial moderno, el declive del Renacimiento o el ancien régime dejado atrás a raíz de la Revolución francesa sigue siendo una parte importante de lo que somos, al menos como límite de precaución absoluta. ${ }^{39}$ En una entrevista con Frode Molven realizada poco después de la publicación del libro, Ankersmit argumentó que mientras las personas sufrieron una pérdida traumática, "cuando lo miras desde la perspectiva de la civilización europea, no la perdimos con los campos de concentración, que eran muy queridos para nosotros. Al contrario, nos alegramos mucho cuando terminó". ${ }^{40}$ Lo que sugieren estas oraciones torpemente traducidas es que nuestro alivio al final del nazismo confirmó nuestra continuidad con la tradición humanista de Occidente, en lugar de señalar su desaparición, por lo tanto, no puede contar como estímulo para experiencias históricas sublimes.

Para que ocurran esas experiencias, afirma Ankersmit, el pasado debe separarse por completo del presente, un proceso que merece el adjetivo "traumático" ${ }^{11}$ para describir su efecto en la mente de los historiadores

38 Ankersmit, Sublime Historical Experience, 351.

39 La afirmación de Theodor W. Adorno en Negative Dialectics, E.B. Ashton, trad. (Nueva York, Seabury Press 1973), 365: "Hitler ha impuesto un nuevo imperativo categórico a la humanidad no libre: ordenar sus pensamientos y acciones para que Auschwitz no se repita, para que no suceda nada similar".

40 Frode Molven, "A Proposal for How to Look at the Past: Interview with Frank Ankersmit", Groningen, diciembre de 2007, ttps://www.scribd.com/document/199536733/InterviewFrank-Ankersmit, 8. Traducción modificada.

${ }^{41}$ Ankersmit, Sublime Historical Experience, 265. Ver también la distinción entre el enfoque de LaCapra en torno al trauma como esencialmente individual y el suyo: "En mi enfoque, sin embargo, 
que registran su impacto. Es necesario que "una antigua identidad se descarte sin piedad, aunque con el mayor dolor, y se transforme en el corazón frío de una nueva identidad. En la vida posterior de una civilización, estas identidades descartadas permanecerán sólo como una ausencia, en la forma en que una cicatriz puede ser el único recordatorio visible de una extremidad amputada". ${ }^{42}$ Alcanzan una especie de estatus cuasi mítico, lo cual las pone "más allá del alcance de los intentos más sostenidos y desesperados de historización. Deben estar situadas en un dominio que esté fuera del tiempo histórico de una civilización. Poseen la más alta dignidad: son lo sublime histórico de una civilización”. ${ }^{43}$

Al llegar al final de Sublime Historical Experience, antes de un breve epílogo sobre Rousseau y Hölderlin, estas oraciones nos alertan sobre lo que está en juego para Ankersmit dentro de nuestras raras experiencias de tales residuos del pasado perdido. Dan crédito a la caracterización ofrecida por Anton Froeyman en su comparación entre Ankersmit y Runia:

Ankersmit describe tanto la experiencia histórica como la sensación histórica como estados mentales conscientes, como un anhelo hacia el pasado como un paraíso perdido, comparable a la nostalgia. El pasado en sí parece atractivo, pero la experiencia de la distancia, de no poder traerlo de vuelta, despierta una experiencia histórica. En el análisis de Runia, sin embargo, no hay un anhelo consciente por el pasado. Por el contrario, el pasado es demasiado terrible y caótico para representarlo, y se impone sobre nosotros y nos hace comportarnos de cierta manera, fuera de nuestro control. ${ }^{44}$

la civilización occidental en sí misma es el tema del trauma; mi pregunta es cómo la civilización occidental, como tal, se enfrentó a sus mayores crisis cuando experimentó la pérdida traumatizante de un viejo mundo porque se vio obligado a entrar en uno nuevo". Sublime Historical Experience, 351.

42 Ankersmit, Sublime Historical Experience, 367-368.

43 Ankersmit, Sublime Historical Experience, 368.

44 Froeyman, "Frank Ankersmit and Eelco Runia," 405. 
Si es nostalgia, una emoción que parece estar en consonancia con las simpatías políticas conservadoras a menudo atribuidas a Ankersmit, ${ }^{45}$ es nostalgia de cierto tipo. En una entrevista realizada en 2007, distinguió entre un tipo que intenta borrar la diferencia entre presente y pasado, y su sublime contraparte histórica, donde "uno es permanente y dolorosamente consciente de esta distancia... y toda la deriva de la nostalgia es el intento siempre infructuoso de superar esta distancia. Éste es el tipo de nostalgia que yo asociaría principalmente con la experiencia histórica: la experiencia histórica es la experiencia de la distancia o la diferencia entre el pasado y el presente". ${ }^{46}$ En su libro, Ankersmit llega a decir que el objeto perdido, llorado por la experiencia sublime, no es un pasado real, que nunca podríamos haber poseído realmente, sino más bien, un mito. "Primero es un mito, en el sentido de que no perdimos nada de lo que habíamos poseído. En segundo lugar, es un mito, en el sentido de que los mitos son aquellas partes de la naturaleza a las que otorgamos el honor de ser parte de nuestra historia". ${ }^{47}$ En otras palabras, la Historia, como algo que es parte de nuestra propia historia, se ha convertido en un objeto extraño que sabemos fuera de nosotros mismos y, sin embargo, por el cual todavía suspiramos, aunque sea en vano.

El anhelo de Ankersmit por un pasado irrecuperable se pone de manifiesto en Sublime Historical Experience, entre otras cosas, por su extensa afinidad por la ornamentación rococó que adoraba de niño. Además de su valor estético y su papel en la historia de la ornamentación, "representa y expresa para mí, un mundo de estados de ánimo y sentimientos. Un mundo de estados de ánimo y sentimientos que tienen su resonancia más

45 Éste no es el lugar para explorar las intervenciones políticas de Ankersmit a lo largo de los años, pero es significativo que durante un tiempo apoyó el Foro para la Democracia, populista de derecha, liderado por Thierry Baudet, el cual abandonó recién en diciembre de 2017.

46 Molven, "A Proposal for How to Look at the Past", 4.

47 Ankersmit, Sublime Historical Experience, 160. 
profunda en mí... los estados de ánimo y los sentimientos definen el lugar donde preferiblemente se llevará a cabo la transición del pasado al presente (y viceversa)". ${ }^{48}$ Lo que evoca para él, confiesa, es nada menos que "el optimismo de la Ilustración y su convicción de que las ciencias nos convertirían en los vencedores del mundo natural", proporcionando una "cura para el aburrimiento y los sentimientos de alejamiento de la realidad". ${ }^{49}$

Dos preguntas inquietantes surgen de este giro argumental de Ankersmit. El primero se refiere a la transición incierta de un encuentro muy personal con el pasado, uno lo suficientemente conmovedor para estimular este tipo de sentimientos poderosos en él, hacia una respuesta más colectiva. Ankersmit comprende a la perfección que su nostalgia por el rococó es idiosincrásica y está arraigada en sus experiencias infantiles con la enfermedad, el aburrimiento y la fascinación que parece haber desarrollado por las decoraciones en el dormitorio de sus padres. Pero si las experiencias históricas sublimes dependen de tales circunstancias individuales, es difícil que lleguen a emblematizar el sentido de pérdida irreversible de toda una cultura. Ankersmit, a menudo, enfatiza la naturaleza comunitaria de la pérdida experimentada y, sin embargo, sus ejemplos personales socavan inadvertidamente esa suposición.

En segundo lugar, la cuestión de lo que se lamenta comunitariamente del mundo perdido tiene que abordar la objeción inevitable de que una actitud colectiva diferencial, tal vez disputada en lo interno, acompañó a la pérdida cuando ocurrió y probablemente sobrevive en nuestras propias respuestas contrastantes sobre ella. Tomemos, por ejemplo, la nefasta leyenda de la "causa perdida" de los derrotados Estados Confederados de América, los cuales alimentaron la nostalgia de la supremacía blanca durante generaciones, pero resultó profundamente repugnante para los es-

\footnotetext{
48 Ankersmit, Sublime Historical Experience, 306-309.
}

49 Ankersmit, Sublime Historical Experience, 306. 
clavos emancipados y sus descendientes. La supuesta defensa heroica de los valores sureńos anteriores a la guerra fue para los oprimidos cualquier cosa menos sublime, y el contacto con los residuos físicos de ese pasado —banderas, uniformes, plantaciones restauradas y cosas por el estiloevocaba sentimientos muy diferentes, similares de hecho a aquellos que Ankersmit nos atribuye a todos nosotros a raíz del Holocausto. Si a este último se le prohíbe evocar experiencias históricas sublimes porque no queremos que vuelvan, lo mismo ocurre con el sur anterior a la guerra, al menos para quienes se resisten a la narrativa supremacista blanca de su heroica, aunque vana, nobleza. Puedo imaginar una resistencia comparable a los encantos del diseño rococó por parte de aquellos que lo identifican principalmente con la opulencia y la frivolidad aristocráticas. La pérdida del viejo mundo puede haber sido traumática para algunos, pero seguramente liberadora para otros.

¿Cuán fatales son estas conclusiones para la defensa de Ankersmit de la experiencia histórica sublime? Como lo sugiere la resonancia que tuvo para dar sentido a mi propio encuentro con las esposas de Gavrilo Princip, así como para las cuatro imágenes de Auschwitz discutidas por Didi-Huberman, no creo que sean tan dañinas. La conexión entre la experiencia que describe Ankersmit y el duelo por un mundo cuya pérdida se lamenta más de lo que se celebra es, diría yo, externa a la descripción de la experiencia en sí. Es decir, lo que sirve como punctum en una fotografía, resistiendo la absorción en un reconfortante marco narrativo o representativo, puede presentarse en formas diferentes. El poder del pasado para movernos en el presente no depende de que se sienta como la lamentable pérdida de algo tan total como una civilización en duelo de una era diferente. La sublimidad, después de todo, puede implicar tanto terror como asombro, y estar acompańada de sentimientos de asombro que superan al espectador. A menudo está relacionada con la violencia y la destrucción a una escala que eclipsa la imaginación individual, algo que ciertamente caracteriza cualquier encuentro tardío con el Holocausto. 
Es aquí donde la relevancia de los residuos fotográficos del pasado, o al menos de algunos de ellos, entra, por así decirlo, en foco. ${ }^{50}$ Como señala el propio Ankersmit en su evocación de la distinción de Barthes entre el studium y el punctum de las fotografías, este último interrumpe el potencial narrativo codificado e inteligible del primero. No proporciona un flujo continuo de memoria en donde el pasado y el presente se complementan, sino que opera como lo que los psicoanalistas llaman un "objeto parcial", desencadena el deseo de lo que no se puede restaurar o reparar. Es un efecto accidental, contingente y no planeado por el fotógrafo, que excede los intentos hermenéuticos de desactivar su inexplicable carga emocional. Barthes entiende su poder como más metonímico que metafórico, gesticulando hacia lo que llama "un más allá sutil, como si la imagen lanzara el deseo más allá de lo que nos permite ver". ${ }^{11}$ De forma significativa, no es el deseo por un futuro feliz, ya que está resueltamente dirigido hacia el pasado. Pero no funciona a la manera de una magdalena proustiana, que restaura el pasado perdido en una reconfortante ensoñación de reconciliación y curación. En cambio, produce una conciencia intensificada de lo irrecuperable del pasado y el trauma de una pérdida que no se pueden compensar, así como un estremecimiento al reconocer que nosotros también estamos destinados a morir y quedarnos atrás.

Como tales, las fotografías históricas pueden compararse con los "acontecimientos" inesperados, notorio foco de la reciente discusión teórica, interrupciones no preparadas o anticipadas en el curso normal de las cosas que desafían la contextualización y se niegan a integrarse en

50 Para un análisis más extenso del siguiente argumento, ver mi "Photography and the Event", en Olga Shevchenko (ed.), Double Exposure: Memory and Photography (New Brunswick: Transaction Publishers, 2014), 91-111.

51 Barthes, Camera Lucida, 59. 
las narrativas del desarrollo. ${ }^{52}$ Sin duda, tales acontecimientos pueden entenderse como prefiguraciones de un regreso, como en el caso de la encarnación de Jesús, que para los cristianos creyentes es la incursión del tiempo kairótico en el flujo de cronos y anticipa una parusía a su fin. La doctrina de la presencia real, que especulamos como una posible forma de dar sentido a la experiencia histórica sublime, podría entenderse como posicionar la Eucaristía como lugarteniente para esa segunda venida, una especie de pagaré para los creyentes de que el Redentor regresará. Aquí la presencia se transforma sutilmente en presentimiento. Aunque Ankersmit, sin duda, se resistiría a la reducción de su teoría a una versión secularizada de esta premisa teológica, su anhelo nostálgico por un pasado perdido, que encuentra un alivio momentáneo en las sensaciones históricas de lo que de él queda, puede sugerir una posible similitud.

Sin embargo, es importante registrar que Ankersmit también reconoce la imposibilidad de esta travesía. De hecho, en algunos de sus estados de ánimo, cuando no está meditando románticamente sobre uniones místicas o besos extáticos, podríamos decir que incluso se acerca a esa versión específicamente judía de la redención invocada por Didi-Huberman, la cual expresa un "absoluto pesimismo" sobre semejante restauración.

52 Baer, Spectral Evidence. Para mayores consideraciones sobre el "acontecimiento", consultar Robin Wagner-Pacifici, What is an Event? (Chicago: University of Chicago Press, 2017), y mi "Historicism and the Event”, en Against the Grain: Jewish Intellectuals in Hard Times, Ezra Mendelsohn, Stefani Hoffman and Richard I. Cohen, eds. (Nueva York: Berghahn, 2014), 143-167. Aunque Ankersmit normalmente designa la experiencia de los historiadores, más que los eventos del pasado, como "sublime", no obstante afirma que "podemos discernir en la historia de Occidente varios momentos en los que repudió radicalmente su pasado anterior en un movimiento que posee todas las características de lo sublime histórico de Hegel. Piénsese, de nuevo, en la Revolución francesa, o en esa otra tremenda revolución ocasionada por la transición de una sociedad agraria y feudal a una sociedad industrial moderna. Pocos eventos en la historia occidental han sido discutidos tan intensamente por los historiadores...”. Sublime Historical Experience, 366. Aunque la Revolución francesa se incluye habitualmente entre las rupturas radicales que cuentan como un "acontecimiento" transformador, el largo, lento y desigual proceso de modernización no lo es. 
Debido a su arrepentida aceptación de la cualidad "disociada" de los momentos de reconocimiento sublime que no pueden ser historizados, al derrotar los intentos por explicarlos, interpretarlos o juzgarlos epistemológicamente, nos permite ampliar su alcance. Más que cifrados míticos de un lamentado "mundo que hemos perdido", también nos ponen en contacto con los residuos demoníacos de un mal radical que se burla de cualquier narrativa histórica complaciente de progreso o desarrollo. Nos recuerdan, en resumen, que el amor entre Romeo y Julieta no sólo fue un desafío a las asfixiantes costumbres de su época, sino también la causa inadvertida de su catástrofe compartida. 